1976

\title{
Archaeological Investigations at sites near Natalia, Medina County, Texas
}

Thomas R. Hester

Center for Archaeological Research

Thomas C. Kelly

Follow this and additional works at: https://scholarworks.sfasu.edu/ita

Part of the American Material Culture Commons, Archaeological Anthropology Commons, Environmental Studies Commons, Other American Studies Commons, Other Arts and Humanities Commons, Other History of Art, Architecture, and Archaeology Commons, and the United States History Commons

Tell us how this article helped you.

This Article is brought to you for free and open access by the Center for Regional Heritage Research at SFA ScholarWorks. It has been accepted for inclusion in Index of Texas Archaeology: Open Access Gray Literature from the Lone Star State by an authorized editor of SFA ScholarWorks. For more information, please contact cdsscholarworks@sfasu.edu. 


\section{Archaeological Investigations at sites near Natalia, Medina County, Texas}

Creative Commons License

(c) (i) (8)

This work is licensed under a Creative Commons Attribution-NonCommercial 4.0 International License 


\section{Archaeological Investigations at sites near Natalia, Medina County, Texas}

THOMAS R. HESTER AND THOMAS C. KELLY

CENTER FOR ARCHAEOLOGICAL RESEARCH THE UNIVERSITY OF TEXAS AT SAN ANTONIO ARCHAEOLOGICAL SURVEY REPORT, NO. 20 
ARCHAEOLOGICAL INVESTIGATIONS AT SITES

NEAR NATALIA, MEDINA COUNTY, TEXAS

Thomas R. Hester and Thomas C. Kelly

Center for Archaeological Research The University of Texas at San Antonio Archaeological Survey Report, No. 20

1976 


\section{TABLE OF CONTENTS}

$\begin{array}{lr}\text { Table of Contents } & \text { Page } \\ \text { List of Figures } & i \\ \text { Introduction } & i \text {. } \\ \text { Previous Archaeological Research } & 1 \\ \text { Field Investigations } & 1 \\ \text { Results of the Field Investigations } & 4 \\ \text { Conclusions } & 14 \\ \text { References } & 15 \\ \text { Appendix 1 } & 16 \\ \text { Appendix } 2 & 17\end{array}$




\section{LIST OF FIGURES}

Figures

Page

1. Archaeological Sites Near Natalia, Texas

2. Archaeological Site 41 ME 18

3. Archaeological Sites 41 ME 19 and 41 ME 20

4. Artifacts from Site 41 ME $19 \quad 10$

5. Flake Assemblage at Site 41 ME 19

11 


\section{INTRODUCTION}

In January, 1976, Hayden Whitsett, archaeologist for the Texas Water Quality Board, carried out an initial archaeological reconnaissance of areas to be affected by the construction of new sewage treatment plant and Tines in Natalia, Texas (Medina County WCID \#3; Whitsett 1976). As a result of Whitsett's survey, five archaeological sites (41 ME 18-ME 22) were documented, and Whitsett suggested (ibid: 1) that four of these might be eligible for nomination to the National Register of Historic Sites.

Subsequent to his reconnaissance, Whitsett contacted the Center for Archaeological Research, The University of Texas at San Antonio, regarding a "Step 2" archaeological testing program at the four sites thought to be of possible National Register quality. An agreement to conduct the needed testing was reached between the Center and the firm of Groves, Fernandez, Barry, Telford and Associates, Inc., the authorized representatives of the Medina County Water Control and Improvement District. A plan of study outlining the proposed testing program of the Center for Archaeological Research was filed with both the Texas Water Quality Board and the Texas Historical Commission.

We would like to express our gratitude to Mr. Hayden Whitsett (Texas Water Quality Board, Austin), Mr. John P. Evan (Groves, Fernandez, Barry, Telford and Associates, San Antonio), and Mr. C. E. Richardson (President, Medina County Water Control and Improvement District, Natalia) for their assistance with the various facets of this project.

\section{PREVIOUS ARCHAEOLOGICAL RESEARCH}

At the time of this writing, only 23 archaeological sites had been recorded in Medina County, and most of these are from the northern part of the county. Most of the site documentation has been done by amateur archaeologists; for example, L. W. Patterson (Houston, Texas) has recorded sites 41 ME 3 (cf. Patterson 1975) and 41 ME 9-17, al1 in northern Medina County. Professional archaeologists have done work at a few sites (e.g., Whitsett 1976) and the only excavations have been at the historic Landmark Inn in Castroville.

That part of Medina County in which Natalia is located falls within the south Texas coastal plain, an area whose prehistory has been described in several recent publications (cf. Hester 1974; Hester and Hil1 1975; Hester 1975a, 1976). Four major chronological periods are recognized for the south Texas region: the Paleo-Indian (ca. 9200 B.C. to 6000 B.C.), the Archaic (ca. 5000 B.C. to A.D. 1000), the Late Prehistoric (or Neo-American; A.D. 1000 to historic contact), and the Historic (the period of historic European intrusion). Given our present knowledge of the regional prehistory, one can safely predict that all of these periods are represented in the archaeological inventory of Medina County. It is essential that the archaeology of Medina County receive careful attention in the years ahead. The hunting and gathering Indian groups 
Figure 1. Archaeological Sites Near Natalia, Texas. The locations of archaeological sites 41 ME 18 - 41 ME 22 are shown. The sites were originally recorded by Whitsett (1976). 
This page has been

redacted because it

contains restricted

information. 
who 1 ived in the area over the past 11,000 years left an interesting, but fragile, archaeological record. The proximity of Medina County to the metropolitan San Antonio area will probably lead to increasing development of various kinds in the future. The irreplaceable archaeological resources of the area should be taken into account when such modifications are being planned.

\section{FIELD INVESTIGATIONS}

The field work of the Center for Archaeological Research in connection with this project was under the overall supervision of Dr. Thomas R. Hester, Director of the Center. Field archaeologist in direct charge of the investigations was Thomas C. Kelly, research associate of the Center.

As noted earlier, Whitsett (1976) had identified five sites, 41 ME 18$41 \mathrm{ME} 22$, during his initial survey. Of these, sites $41 \mathrm{ME} 18,41 \mathrm{ME}$ 19, $41 \mathrm{ME} 20$, and $41 \mathrm{ME} 21$ had been recommended for testing, in order to provide a better evaluation of their potential for nomination to the National Register. Each of these sites, as well as site $41 \mathrm{ME} 22$, has been described in detail in Whitsett's (1976) report and these descriptions are not repeated here (site locations are shown in Figure 1).

All of the sites in question were revisited by the UTSA field team. An intensive search was made of the surface of each site and the surrounding area. Whenever a concentration of a few flakes (or other evidence of aboriginal habitation) was noted, a shovel test of $50 \mathrm{x}$ $50 \mathrm{~cm}$ was excavated, and al1 deposits passed through 1/4-inch screen. If subsurface deposits were located via the shove1-testing procedure, 1 meter square units were established and controlled 10 or $15 \mathrm{~cm}$ arbitary levels were excavated, with the deposits screened through 1/8inch mesh. These excavations were carried out according to standard archaeological techniques (cf. Hester, Heizer, and Graham 1975).

Materials recovered through surface and subsurface investigations were taken to the Center laboratory for processing and analysis.

\section{RESULTS OF THE FIELD INVESTIGATIONS}

\section{ME 18}

The site area encompasses the proposed location of the planned sewage disposal plant. It lies in a field between Fort Ewell Creek on the west, and an extension of Sixth Street just south of Natalia (Figures 1, 2). The access road from Sixth Street near the north edge of the field proceeds west past an old gravel quarry, turns south across an intermittent branch of Fort Ewe11 Creek, and proceeds uphill to the south boundary fence. The field is cultivated east of this road with uncultivated brush west to Fort Ewell Creek. Heavy erosion near the creek bank has exposed yellow clay and decomposed sandstone.

A meticulous surface search failed to find any concentration of archaeological material, although a thin scatter of chert debitage and a core 
Figure 2. Archaeological site $41 M E$ 18. Indicated in the figure are the locations of several shovel tests excavated at the site. Two concentrations of cultural material are enclosed with dashed lines near the corral in the lower part of the figure. Contour intervals are in feet. 
This page has been

redacted because it

contains restricted

information. 
were observed along and mostly south of the south boundary fence. Eight flakes were found in an area of approximately six meters in diameter, four meters north of a corral near this area located only five additional small flakes. In an effort to locate buried deposits, a series of tests were made (Figure 2), but no subsurface archaeological materials were found.

We do not believe that the planned sewage disposal plant will cause any harm to archaeological resources.

\section{$41 \mathrm{ME} 19$}

This late prehistoric site extends for approximately 30 meters along the east bank of a smal1 tributary creek. This drainage intersects Fort Ewel1 Creek 70 meters southeast of the U.S. Highway 81 bridge on the south edge of Natalia. The site lies in and west of a fenced rightof-way that is an extension of Third Street, south of its intersection with Bennet Street (Figure 3). Four one meter squares and 11 shovel tests were excavated to 50 centimeters. The maximum depth of cultural materials at the site never exceeded 25 centimeters, and the bulk of these remains were recovered from the upper 15 centimeters.

The detailed excavation report is on file at the Center. A summary of the findings follows.

\section{Lithics}

Three very well made Perdiz arrow points were found; Figure 4, a, is representative. On this specimen the flake scars run five or six to the linear centimeter and would seem to have required a flaking tool with a needle-like point. A thin blade with the bulb of percussion removed and with finely flaked ventral edges (Figures 4 , b) is probably the preform for another Perdiz point. Two fragmented blades were also recovered. Unfortunately, no cores or any large pieces of chert were found in the site. The scarcity of primary flakes is a further indication that the decortication and initial reduction of the raw chert took place elsewhere. No source of chert was observed anywhere in the survey area yet the large chert cobble hearth of recent vintage across the creek in $41 \mathrm{ME} 20$, indicates a good source somewhere nearby.

Three "microlithic" specimens would appear to indicate the use of small tools. The wear patterns on the recovered examples include polished striations parallel to the edges.

Similar striations are found on the specimen shown in Figure $4, d$. It is an alternately beveled biface and there are a few overlapping flake scars indicating resharpening. Another alternately beveled specimen is illustrated in Figure $4, c$. This artifact is made on a flake which retains a massive cone of percussion at the proximal (striking platform) end. The distal portion of the flake has been alternately trimmed on the lateral edges. 
A total of 710 primary, secondary, and interior flakes was recovered from the four excavated one meter squares, A to D (Figure $4, j, k$ ). Their distribution by square and level is shown in Figure 5 . The shovel tests, shown in Figure 3 , revealed sterile gaps in flake and artifact distribution within the 5 by 30 meter area of the site. Squares $A$ and $C$ are parts of one discrete area, but are discontinuous from squares $B$ and $D$ which are also separated by sterile areas. Some specialization of knapping activities is revealed by the flake analysis. Some primary flakes were being removed in the area of squares $A$ and $D$ although their low percentage indicates the use of nodules at least partially decorticated elsewhere.

A low percentage of hard hammerstone flakes was present, and most of the knapping was done with a fairly light soft hammer, with finishing done by very fine pressure flaking. Very small striking platforms, diffuse bulbs of percussion, and lipped flakes predominate.

A very smal1 and nondescript hearth of eight burned sandstone rocks was found in the northwest corner of square $C$ at 10-17 centimeters in depth. This hearth is quite similar to one excavated by the authors in the late prehistoric sites on the Chaparrosa Ranch in Zavala County, southern Texas.

\section{Ceramics}

Nine potsherds (Figure $4, e-i$ ) possibly all from the same vessel, were found. All were typical bone tempered plain ware typical of the southern Texas late prehistoric and fall into Hester and Hi11's (1971: 197) Group A. These are tempered finely with ground bone and grit. They have slightly burnished buff exteriors (some smoke-stained) and with grass or twig-brushed buff to black interiors. The rims were thinned from the inside, flare out slightly, and are slightly rounded at the rim edges. Vessel walls are uniform, 5 to 6 millimeters in thickness.

Bone

No bone artifacts were found, but a small sample of burned and unburned bone fragments were found. Only whitetail deer and Bison, or possibly cow, were identified and al1 specimens were from adult animals. An analysis of the recovered faunal remains is found in Appendix 1 .

She11

Several decomposed fragments of mussel shell were found, but there were no accumulations which would indicate it was an important dietry item. Snails, mostly the common large Rabdotus, were found in the two upper excavated levels only.

\section{Palynological Analysis}

During the course of the excavations at 41 ME 19, a series of soil samples was taken. It was hoped that the palynological analysis of these 
This page has been

redacted because it

contains restricted

information. 

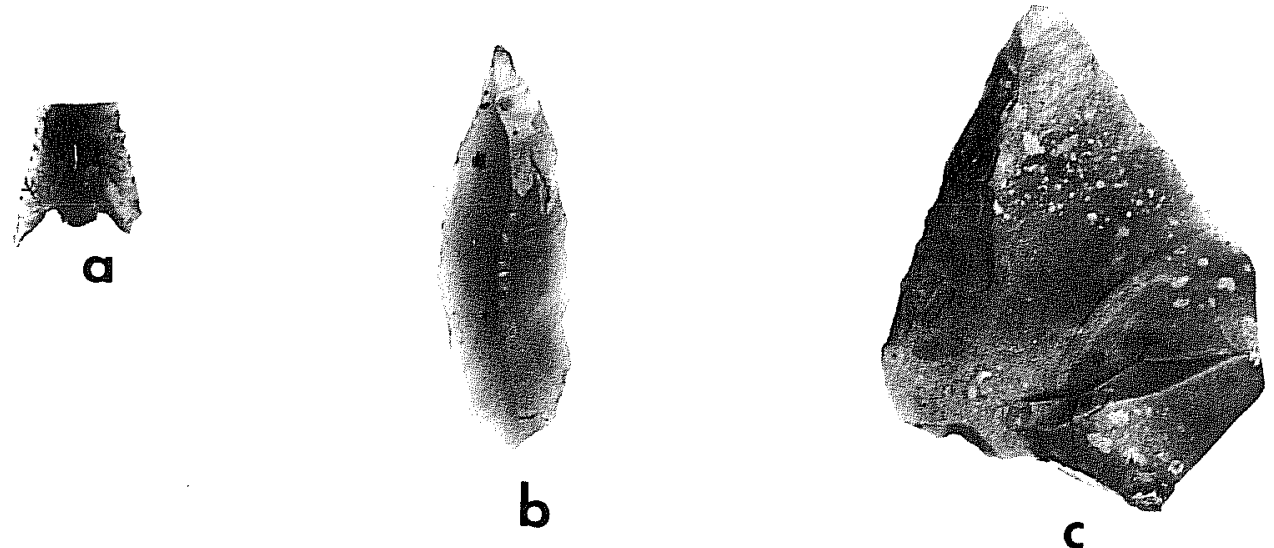

b
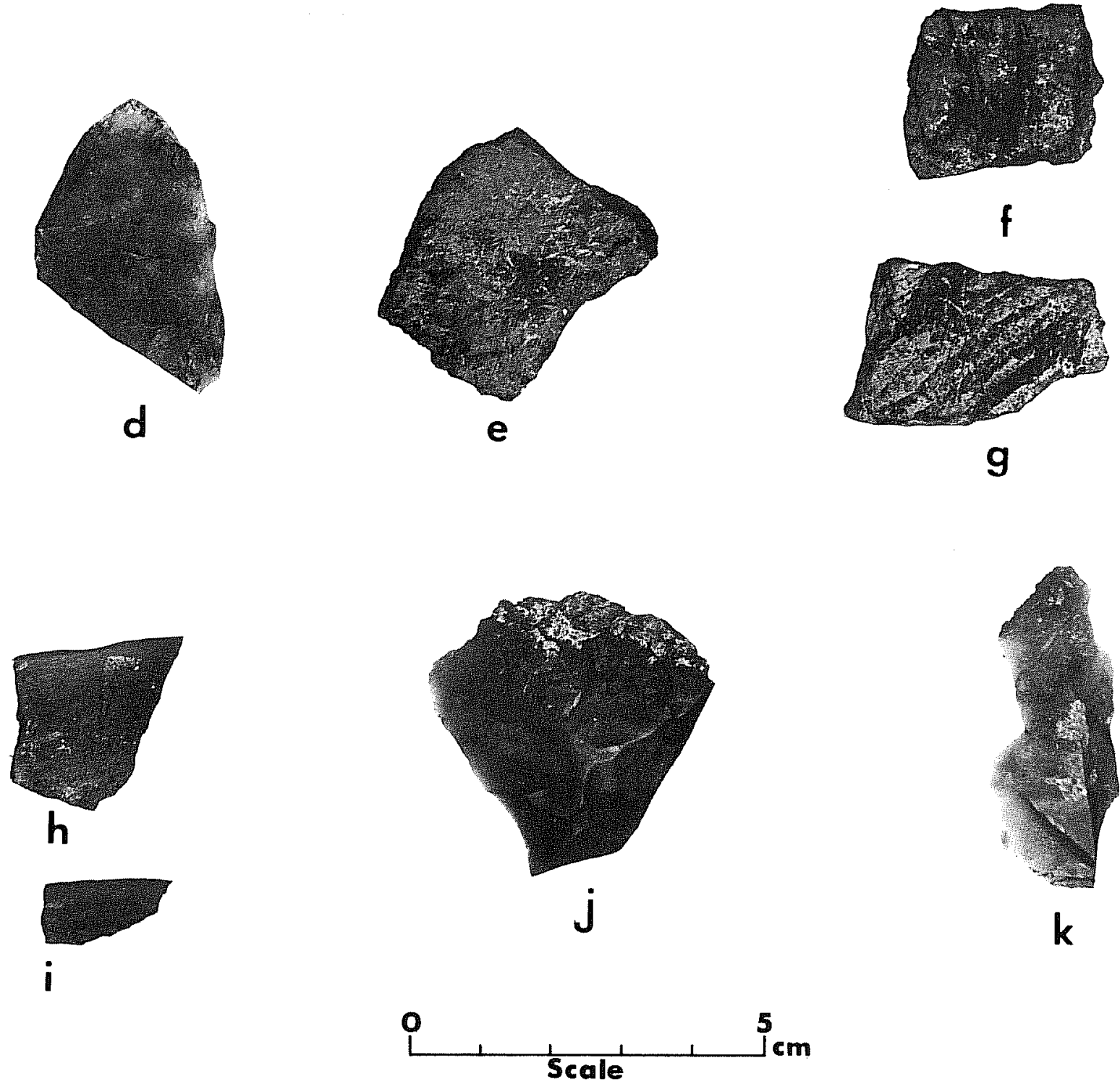

Figure 4. Artifacts from Site 41 ME 19. a, Perdiz arrow point; b, trimmed blade; c, alternately beveled flake; $d$, fragment of alternately beveled biface; $e-i$, potsherds ( $h, i$ are rimsherds); $j, k$, flakes. 
Figure 5. Flake Assemblage at Site 41 ME 19. The histograms i1lustrate the distribution of primary, secondary, and interior flakes by unit and level at site $41 \mathrm{ME}^{\prime} 19$. The actual number of flakes in each category is shown just below the histograms. The left column represents primary flakes, the central column, secondary flakes, and the right column, interior flakes. 
$\%$

100
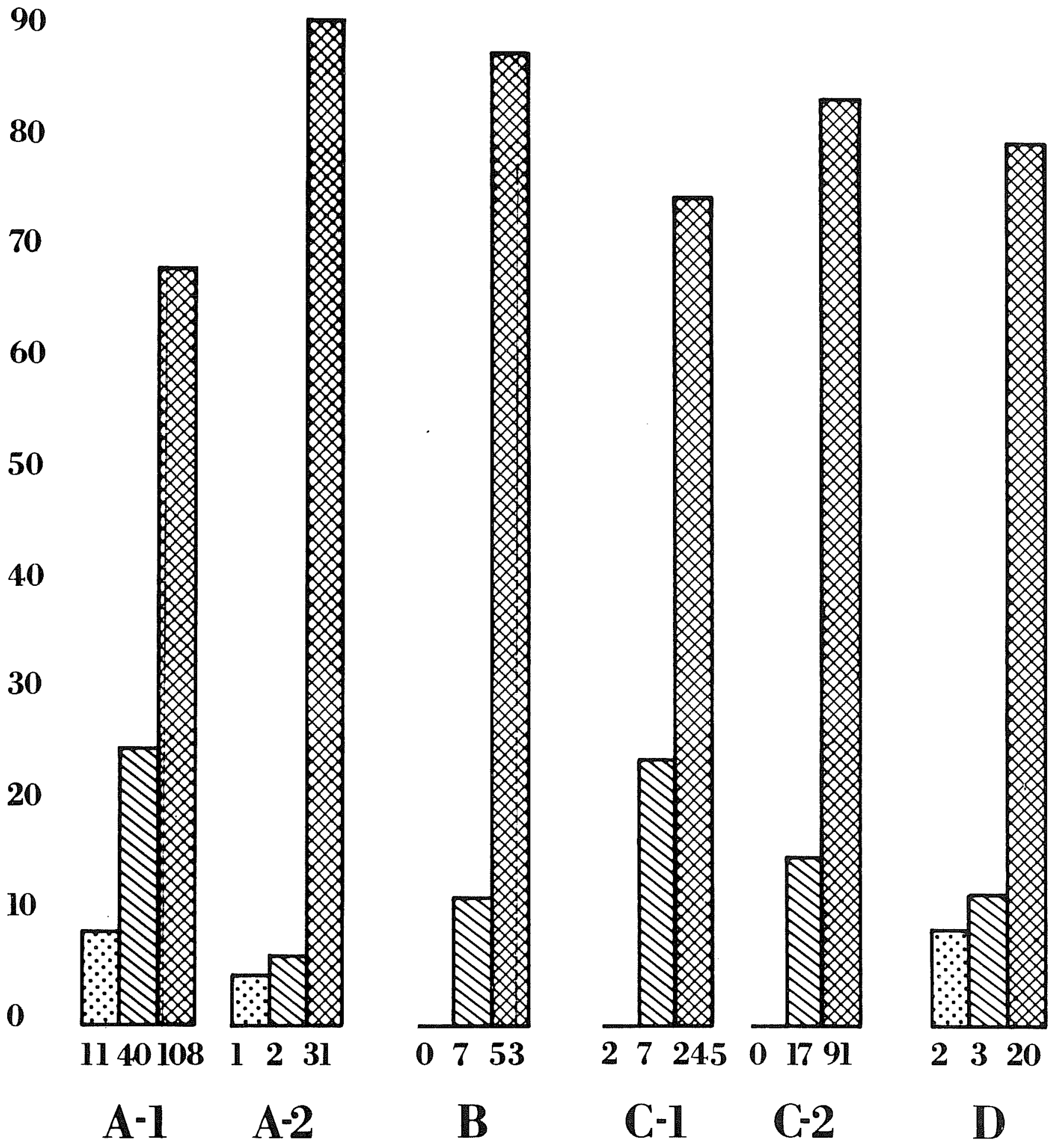

B

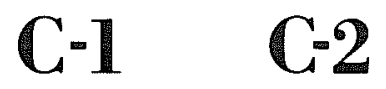


samples might yield data on the environmental conditions in the area at the time of the late prehistoric occupation. The samples were submitted to Dr. Vaughn M. Bryant, Jr. at Texas A \& M University. The results of his studies are found in Appendix 2 .

\section{Comments}

41 ME 19 is a sma11 late prehistoric campsite which probably saw short term (one time?) occupation. The material remains recovered at the site, principally Perdiz arrow points and bone-tempered pottery, are quite similar to a number of late prehistoric components reported by Hester and HiTl (1971, 1975) and Hester (1975b) from other sectors of the coastal plain. Radiocarbon dates suggest that such sites date around A.D. 1300. This is a significant site in terms of the potential information it could yield on late prehistoric occupations in southern Texas. Large scale excavations at the site could conceivably yield information on site patterning, and would certainly produce additional information on material culture and subsistence. However, it is our opinion that the main occupation areas of the site lie well outside the route of the proposed sewage 1 ines.

Because of the shallow depth of the deposits, the site could suffer total destruction if large, tracked-wheel vehicles traversed it during pipeline construction activities. For this reason, we recommend that such vehicular activity on the main part of the site (see Figure 3 ) be strictly prohibited. 41 ME 19 should be nominated to the National Register of Historic Places.

\section{ME 20}

Reconnaissance by Whitsett (1976) indicated the presence of a site on the north side of Fort Ewell Creek on both sides of the U.S. Highway 81 bridge at the south edge of Natalia (Figures 1,3). It was thought to be possibly a westward extension of 41 ME 19.

Shovel tests located an extensive buried hearth in a state of almost perfect preservation (see Figure 3). A one-meter square was excavated, revealing the southeast quadrant of a hearth (of large chert cobblestones) 1.5 meters in diameter. However, beer bottles, tin cans, and other 20th century artifacts were found above and below the hearth, to a depth of 35 centimeters. Obviously, the hearth is of historic non-Indian origin. An intensive surface search failed to locate any evidence of prehistoric occupation on either side of the Highway 81 bridge.

No further action is deemed necessary at this locality.

\section{$41 \mathrm{ME} 21$}

The site lies at the confluence of a small slough and Fort Ewell Creek west of the intersection of Kearney Street and U.S. Highway 8] in Natalia (Figure 1). Ground visibility was good in contrast to the 
time of the January survey (Whitsett 1976) when it was obscured by vegetation. Scattered flakes were found in the cowtrail mentioned by Whitsett (ibid: 4). Carefully excavated shovel tests failed to locate any significant buried deposits, although a few flakes occurred in the top 10 centimeters in the highest part of the creek bank. The creek banks are almost vertical in this area and provide an excellent cross-section; however, no archaeological materials were found to be exposed in them.

It may be that the thin 1 ithic scatter of smal1 flakes found at 41 ME 21 are derived from a site presently covered by Kearney Street and U.S. Highway 81 in Natalia. At any rate, we do not recommend any further work at this site.

\section{CONCLUSIONS}

Intensive archaeological survey and a limited testing program at four sites near Natalia, Texas, were carried out by the Center for Archaeological Research, The University of Texas at San Antonio. Of the four sites, only one (41 ME 19) yielded significant archaeological information. It is our opinion that this site should be nominated to the National Register of Historic Places. The site will not be affected by the proposed sewage line route; however, care should be taken, during the construction phase, not to modify the upper portions of the site adjacent to the sewage line route. The other three sites, 41 ME 18, 41 ME 20, and $41 \mathrm{ME} 21$, were found to have very scattered archaeological evidence and had no buried deposits of any importance. We do not bel ieve that any of them should be nominated to the National Register. Furthermore, the construction of the proposed sewage plant and lines on or in the vicinity of these three sites will not have any harmful effects on local archaeological resources. 


\section{REFERENCES CITED}

Hester, T. R.

1974 A Bibliographic Guide to the Archaeology of Southern Texas. Journal of South Texas 1: 18-36.

1975a An Overview of Prehistoric Chronology in Southern and South Central Texas. To appear in: Prehistory of Northeast Mexico and Texas, Monterrey. In press.

1975b Late Prehistoric Cultural Patterns Along the Lower Rio Grande of Texas. Bulletin of the Texas Archeological Society 46: 107-126.

1976 Hunters and Gatherers of the Rio Grande Plain and Lower Coast of Texas. Center for Archaeological Research, The University of Texas at San Antonio. Mimeographed.

Hester, T. R. and T. C. Hi11, Jr.

1971 An Initial Study of a Prehistoric Ceramic Tradition in Southern Texas. Plains Anthropologist 16: 195-203.

1975 Some Aspects of Late Prehistoric and Protohistoric Archaeology in Southern Texas. Center for Archaeological Research, The University of Texas at San Antonio, Special Reports 1.

Hester, T. R., R. F. Heizer and J. A. Graham

1975 Field Methods in Archaeology. 6th Revised Edition. Mayfield Publishing Company, Palo Alto.

Patterson, L. W.

1975 A Quarry Site in Medina County, Texas. La Tierra 2(1): 19-23.

Whitsett, H.

1976 Archeological Reconnaissance of Medina County WCID \#3. Report submitted to the Texas Water Quality Board. $6 \mathrm{pp}$. + map. 
Appendix 1

FAUNAL REMAINS FROM SITE 41 ME 19

The following identifications of animal bones recovered from the text excavations at 41 ME 19 were done by Billy Davidson (Austin, Texas).

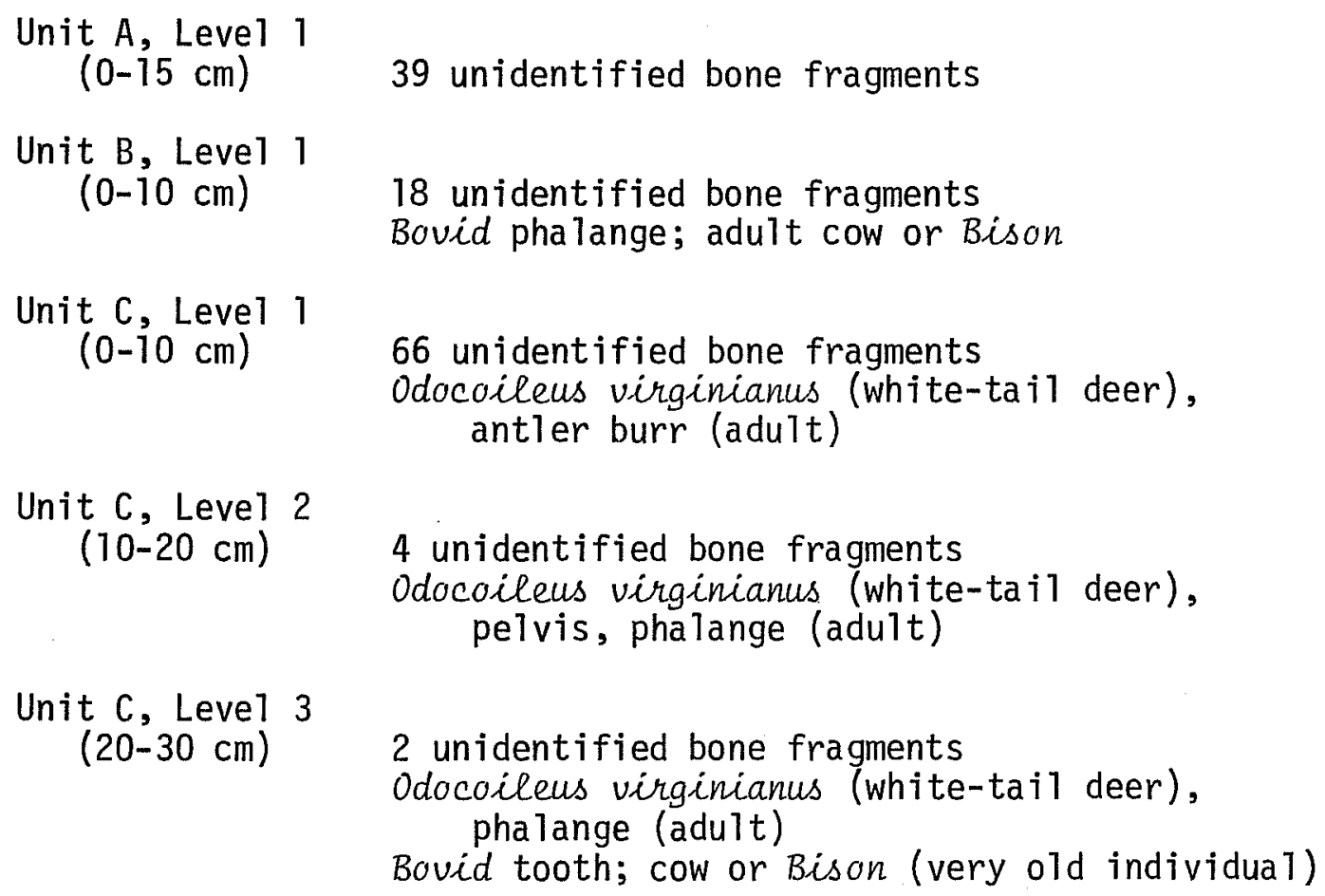




\author{
Appendix 2 \\ POLLEN ANALYSIS OF FOUR SAMPLES FROM SITE
}

41 ME 19, MEDINA COUNTY, TEXAS

Vaughn M. Bryant, Jr.

This report represents the results of a pollen analytical study conducted on four soil samples collected from archaeological site 41 ME 19 located on Fort Ewel1 Creek in Medina County, Texas. Since these soil samples were collected from an area where suspected pollen preservation is poor we decided to try a variety of new processing techniques in order to see if we could increase our fossil pollen yield. These procedures are as follows:

\title{
Procedure \#1
}

1. 50 grams of soil was selected from each sample for analysis

2. Each sample was screened and decanted to remove 1 arge grained silicates

3. Placed in concentrated HF for 24 hours

4. Washing in boiling $10 \% \mathrm{HCl}$ three times

5. Concentrated Nitric Acid for 10-15 minutes

6. Zinc chloride (sp. gr. 1.90) for 20 minutes at 2000 RPM

7. Sodium hypochloride (5\%) 3 drops added to concentrated $\mathrm{HC} 1$

8. Concentrated ammonia rinse

\section{Procedure \#2}

1. 50 grams of soil was selected from each sample for analysis

2. Each sample was screened and decanted to remove large grained silicates

3. Concentrated HF for 24 hours

4. Washed in boiling $10 \% \mathrm{HCl}$ three times

5. Zinc chloride (sp. gr. 1.90) for 20 minutes at 2000 RPM

\section{Procedure \#3}

1. 50 grams of soil was selected from each sample for analysis

2. Each sample was screened and decanted to remove large grained silicates 
3. $10 \% \mathrm{KOH}$, heated to boiling

4. Wash in boiling $10 \% \mathrm{HCl}$

5. Concentrated HF for 24 hours

6. Zinc chloride (sp. gr. 1.90) for 20 minutes at 2000 RPM

7. Acetolysis-(mixture of sulfuric acid and acetic anhydride) placed in boiling water bath for 15 minutes

8. $10 \% \mathrm{KOH}$, heated to boiling

Procedure \#4

1. 50 grams of soil was selected from each sample for analys is

2. Each sample was screened and decanted to remove large grained silicates

3. $10 \%$ heated $\mathrm{HCl}$

4. Washed in cold water

5. Concentrated HF for 24 hours

6. Acetolysis-(mixture of sulfuric acid and acetic anhydride) placed in boiling water bath for 15 minutes

7. $10 \%$ Nitric Acid, boiled for one minute

8. Washed in cold water

The results of these tests showed that pollen could not be recovered in sufficient quantities using any of the above procedures. Some minor differences in the results did occur but appear to be negligible in view of our negative results. Funga 1 spores were present in al1 four samples and some flecks of charcoal were also noted in most samples. No recognizable whole pollen grains were seen in any samples yet a few small fragments of what appeared to be badly deteriorated pollen grains were noted. The identities of these small fragments were difficult to derive yet some appeared to be members of the grass and composite plant families. At least one fragment of a pine pollen grain was also noted in one sample.

Lack of preserved pollen from these samples could have resulted from any one or a combination of the following causes.

1. The almost total absence of pollen and the presence of at least some fungal spores suggest that some pollen destruction resulted from an attack by fungi. Certain fungi groups rely upon the 
cytoplasm within pollen grains as their primary source of food. These fungi also have the ability to either destroy the pollen wall or weaken it so that other types of mechanical destruction can occur. It is difficult to determine the presence of these fungi in samples prior to actual processing since these fungal types do not occur in all soils nor in all environments.

2. Repeated wetting and drying of the soils would speed the breakdown and oxidation of non-carbonized organic materials, such as pollen. I am unable to determine whether or not this could have acted as one of the causes of pollen destruction in these samples. I suspect that it may have been at least a contributing factor since there was little organic material at all in any of these samples.

3. The presence of small flecks of carbon in one of the samples suggests the repeated use of fires within the site area. This would also tend to speed pollen destruction in those areas immediately under or near hearths.

In summary, I believe that the environment of deposition at site 41 ME 19 is not conducive for pollen preservation. As such I would suggest that additional attempts to recover pollen from similar sites also might result in failure. 